\title{
ANALYSIS OF THE SHADOW ECONOMY AND ITS FISCAL EFFECTS IN UKRAINE
}

\author{
Pavlo Pirnykoza \\ Department of Taxes and Fiscal Policy \\ Ternopil National Economic University \\ 11 Lvivska str., Ternopil, Ukraine, 46000 \\ PavloPirnykoza@gmail.com
}

\begin{abstract}
This article analyses the share of shadow economy in Ukraine and its effects on the domestic fiscal sphere. It was made an attempt to calculate the approximate tax losses, which was resulted by the informal sector of economy. Also, we tried to search the influence of the shadow economy on the consolidate budget revenue, expenditures and deficit. The results of this paper are:

1) the level of the shadow economy in Ukraine during last 5-10 years is between $34-43 \%$ of GDP;

2) the annual average tax losses are about $15.4 \%$ of official GDP, of which $10.4 \%$ is the losses of central and local budgets, $5.0 \%$ is the losses of Ukrainian Pension Fund;

3) it was empirically proven the influence of the shadow economy on the amount and the structure of expenditures of Consolidated Budget of Ukraine. We found strong support that the bigger size of informal sector leads to the reduction of the capital expenditures' share in the general expenditures of Consolidated Budget of Ukraine.
\end{abstract}

JEL Code: E620, O170, H260, H200, C 100.

Keywords: shadow economy, tax losses, consolidated budget, tax revenue, budget expenditure, budget deficit, tax ratio, Ukraine.

\section{Introduction}

Shadow economy is one of most painful problems for a government of any country, especially it concerns Ukraine, where the share of informal sector is considered by scientists as the most in Europe. The great shadow economy volume has an essential negative influence on the financial and economic environment in Ukraine. The shadow economic activity is mainly provoked by the desire of economic subjects to avoid tax payments. Thus, the state suffers from financial losses as a shortening of budget revenues that results in its deficit increase, expenditures decrease or deformation or their structure and so on.

A fiscal crisis in Ukraine that annually causes the growth of the existent national debt threatens the state finances stability. Its overcoming needs a search for additional sources to fill the budget. From our point of view, the shadow economy occupies a special place among them. Widening of the tax base by de-shadowing of the hidden GDP allows the state to involve additional financial resources for covering the existing budget deficit. But before realizing any arrangements for de-shadowing in Ukraine, it is urgent to study peculiarities of the shadow economy development, dynamics of its volumes and to evaluate fiscal effects, caused by it.

The study of shadow economy volumes in Ukraine is realized in works of the famous Austrian professor, expert in the shadow economy sphere F. Shneider. He published both an individual paper on this thematic [1], and several ones in co-authorship, where he and his colleagues estimated the shadow economy level in many countries of the world, including Ukraine [2, 3]. The results of these researches testify that the shadow economy level in our state is one of highest in the world. It allows us to suppose that de-shadowing of the Ukrainian economy may become an effective instrument for filling the budget and sanitating state finances. The quantitative analysis of the shadow sector and peculiarities of its development in Ukraine as realized in works of native scientists $[4,5]$. For this aim there were used data, offered by both foreign experts and native state organizations.

Fiscal results, caused y the shadow economy, were theoretically studied in the work by P. Pirnykoza [6]. In their turn, empirical studies on this thematic were realized in works [7, 8]. Thus, 
they mainly estimated tax losses as a result of the shadow sector functioning in countries-members of the European Union and OECD.

Despite the series of analyzed researches, it can be stated, that the complex estimation of fiscal results of the shadow economy was not realized in Ukraine during the last years, as opposite to European countries. It causes the topicality of this research.

\section{Aim of research}

The complex study of shadow economy volumes and fiscal results of its functioning in Ukraine.

\section{Materials and methods of research}

At realizing this scientific study, there were used general scientific and special methods. Among them the most important are: abstract-logic method; statistical methods; method of comparative analysis and synthesis; calculating-analytic method, method of correlation-regression analysis and so on.

The information base of the research is analytic and statistic reports of Ukrainian and world organizations, especially, the State fiscal service of Ukraine, State statistic service of Ukraine, State treasury service of Ukraine and so on; works of native and foreign scientists on problems of economy de-shadowing and economic security.

\section{Results}

\section{1. Analysis of shadow economy volumes in Ukraine}

The estimation of shadow economy volumes is rather complicated task, because of the activity of economic subjects functioning in the shadow sector is hidden. The problem of determining volumes of the hidden activity is also connected with absence of an integral methodology of estimating this phenomenon that gives distinct results and is used in all countries of the world. So, the volume of shadow economy in Ukraine may be known of three sources: studies of the Ministry of economic development and trade of Ukraine (farther - MEDTU), studies of the State statistic service of Ukraine (farther SSSU) and foreign studies by F. Shneider and his colleagues from the World Bank. Unfortunately, despite the great interest of Ukrainian scientists to the shadow economy, the permanent estimation of its volumes is not realized by them.

The results of the aforementioned studies differ from each other because of using different methods of the shadow economy estimation. Thus, foreign scientists most often use MIMIC-method (Multiple Indicators Multiple Causes Method). It provides that a shadow economy volume is a latent variable, connected on the one side with a certain number of observed indicators (that reflect changes in shadow economy volumes), on the other one, with a set of observed causal variables, considered as most important determinants of the hidden economic activity. Having determined these indicators and variables, we can estimate a shadow economy volume by econometric methods. It is remarkable that at changing collected indicators and variables, obtained results of the shadow economy level change too. So, the shadow economy level in Ukraine in the same year varies in different works of some foreign authors. Such difference may be observed in these three researches [2, 3], which author or co-author F. Shneider is. Totally, the shadow economy level in Ukraine, calculated by foreign scientists, varies within $40-47 \%$ of the official GDP. Thus, the result of one of most complex researches [2] demonstrated that the average shadow economy level in Ukraine for the period 1991-2015 was 44.8\%. This index is the second after Georgia in Europe and 24-th among 158 studied countries of the world. Only such countries as Zimbabwe, Haiti, Gabon, Honduras and other ones are below. According to obtained data, the highest shadow economy level in Ukraine was 57 \% of GDP in 1998, the lowest one - 36.7 \% of GDP in 2008.

SSSU elaborated methodological principles of calculating shadow economy volumes (official name "non-observed economy") [9], that correspond to international standards of the System of national calculations (SNC-93), and uses them regularly. Correspondent principles were elaborated for increasing the quality of GDP estimations, which calculation includes shadow sector volumes [10]. According to this methodology, the shadow economy calculation is based on data 
of annual state statistic observations and administrative information. Its results indicate that the shadow economy level in Ukraine varies within 15-20\% of GDP.

MEDTU uses own methodology, approved by the correspondent order [11] for calculating the shadow sector. This order gives an integral native official definition of the shadow economy: "economic activity of an economic subject, not registered in the established order, characterized by minimization of expenditures for producing goods, making works and giving services, avoiding taxation, fees (compulsory payments), statistic polling, which result is violation of legislative norms (minimal wages level, working day duration, labor conditions and safety and so on)". According to the established methodology, the main methods that help to calculate shadow economy volumes is:

1) «population's expenditures - retail commodity turnover»;

2) «electric method»;

3) «monetary method»;

4) «financial method».

The aforesaid methods of estimation of shadow economy volumes include different spheres of the national economy, so their use demonstrates different results of shadow sector volumes. So, MEDT deduces an integral parameter, based on these methods. It characterizes the shadow economy in Ukraine complexly. Its value varies within 34-43\% of GDP last 5 years.

For comparison, the results of all three estimations of the shadow economy are presented on Fig. 1.

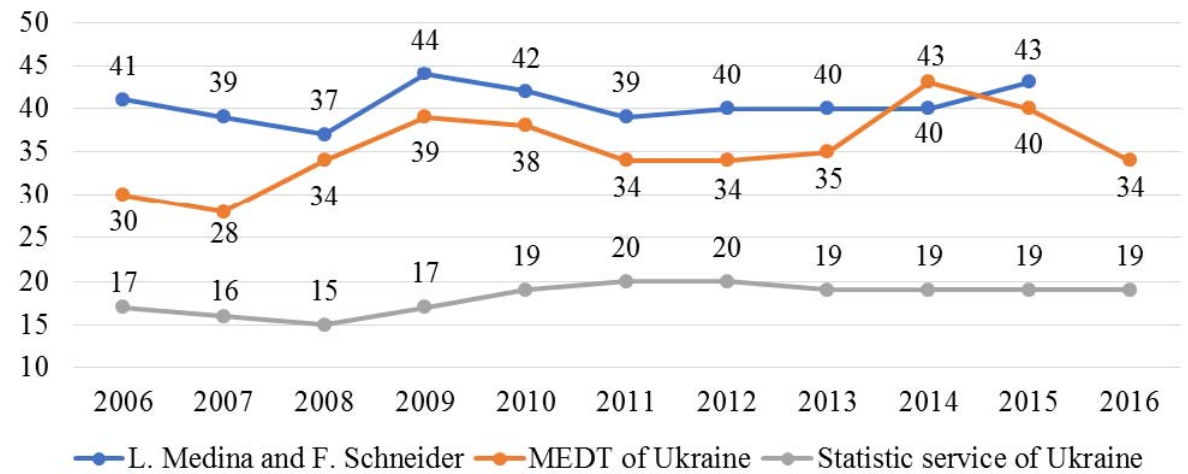

Fig. 1. Shadow economy level in Ukraine, calculated by different methods, \% of GDP. Source: according to data $[2,12,13]$

Comparing the results of calculations of the shadow economy level by two native state organizations, the great difference between them must be noted. If according to SSS of Ukraine, this index for the period 2006-2016 never exceeded $20 \%$ of GDP, the correspondent MEDT data demonstrate that its lowest value was fixed in 2007 and was $28 \%$ of GDP. From our point of view, the indices, offered by SSSU, look a bit non-realistically low comparing with other native and foreign studies, none of which considers the Ukrainian shadow sector as less than 1/3 of GDP. Moreover, the shadow sector level indices, calculated by SSSU, almost don't react on economic conjuncture changes. It is impossible in practice and contradicts to all theoretical bases of the shadow economy. Thus, during the world economic crisis of 2008-2009 the shadow sector level, according to SSSU, was lower than during the relatively stable economic period 2010-2013, that may be doubted. According to the same data, the shadow economy level didn't undergo noticeable changes also after revolutionary events in Ukraine in 2014, whereas calculations of all other studies demonstrated its growth. Despite the fact that we consider SSSU indices as something incorrect, we'll take them into account at the further analysis and calculations, because they are included in the officially calculated GDP of Ukraine.

Comparing the results of calculations by MEDTU and foreign researchers, let's note that researches of former ones usually demonstrate a bit higher level of the shadow economy in Ukraine. If in 2006-2007 this difference was more than 10 p.p., starting from 2008 it varied within 3-7 p.p., at that the result least differed in the period 2009-2014. From our point of view, it testifies to the fact 
that introduction of new methodical recommendations of calculating the shadow economy level in 2009 for MEDT had a positive influence on the estimation distinctness. At the further analysis of fiscal and economic results of the shadow sector functioning in Ukraine we'll use MEDT data, because, at first, they are official, at second, during the last years they don't essentially differ from ones of other foreign studies, at third, may be most distinct because of MEDT possibility to obtain more distinct information, necessary for calculating the shadow economy, from state authorities.

\section{2. Calculation of tax losses through the shadow economy of Ukraine}

Functioning in the shadow economy sector, any economic subject pursues the one aim maximization of personal profits. The hiding of economic activity is inseparably connected with the full or partial non-declaring of incomes from it that allow an entrepreneur to leave non-paid taxes to him/herself, so to get financial advantages over competitors. At the same time such maximization of personal profits by each separate entrepreneur causes essential damages to social ones, because non-paid taxes is the lost financial resource that must help state to satisfy social needs. Thus, the main fiscal result of the shadow economy is tax losses.

The calculation of tax losses from the shadow economy of Ukraine needs first of all to define a tax ratio - an index that reflects the part of GDP, redistributed by central funds of assets using taxes. In other words, it reflects the real level of fiscal load in a country. In this research we have calculated it in Table 1 by the following formula:

$$
T R=\frac{T P+R_{u i f}}{G D P_{o f . t a x}},
$$

where $T R$ - tax ratio; $T P$ - tax proceeds, mln hrn; $R_{\text {uif }}$ - revenue of payments to the funds of the obligatory state insurance, $\mathrm{mln}$ hrn; $G D P_{\text {of.tax }}$ - officially taxed gross domestic product $\left(G D P_{o f}-G D P_{s h_{s S S U}}\right)$ mln. hrn.

The obtained results indicate that in the period 2006-2016 the fiscal load varied within $40.3-47.8 \%$ of GDP. Till 2010 this index had an inessential tendency to decrease, but after activating the tax code, it became to growth, in first turn, at the expanse of budgetary taxes and not social fees (UIF). The fiscal load had reached the highest level in 2012, then it got the constant tendency to decrease and became the least in 2016 at the expanse of liberalization of rates of the unitary fee for the common obligatory social insurance. It must be noted, that after the abrupt change of the political vector in 2014, the budgetary tax load has a tendency to increase, connected with the need of the Consolidated budget of Ukraine (farther CBU) in additional financial resources. It especially concerns the State budget of Ukraine because of the need in financing such directions as defense, serving the national debt and covering the increasing deficit of the Pension Fund of Ukraine [14].

We used the calculated tax rate for calculating state tax losses that include both losses of the Consolidated budget of Ukraine and losses of funds of the obligatory social insurance. Fiscal losses during 2006-2016 are calculated in Table 2 by the formula:

$$
T L=G D R \times \frac{S E}{100} \times T R
$$

where $T L$ - tax losses; $S E$ - shadow economy level;

The results of the calculations demonstrated that average tax losses as a result of the shadow economy in Ukraine in the period 2006-2016 were near $15.4 \%$ of the official GDP. In the period 2009-2015 their volume was stably higher than its mean value, instead of it in the period 20062008 and 2016 - lower. The abrupt decrease of tax losses volumes in 2016 is mainly connected with the shadow economy level decrease and general fiscal load decrease. Tax losses may be conventionally divided in ones of the budget and ones of the state funds of social insurance. The obtained results testify that CBU get less taxes in average by $10.4 \%$ of GDP, funds of state social insurance, in their turn, lose financial resources as $5.0 \%$ of GDP. 
Table 1

Calculation of tax ratio in Ukraine

\begin{tabular}{|c|c|c|c|c|c|c|c|}
\hline Year & $\begin{array}{c}\text { Nominal } \\
\text { GDP, ml. hrn }\end{array}$ & $\begin{array}{c}\text { Officially taxed } \\
\text { GDP (decreased by } \\
\text { SE level, calculated } \\
\text { by SSS of Ukraine), } \\
\text { mln hrn. }\end{array}$ & $\begin{array}{c}\text { Tax reve- } \\
\text { nues of the } \\
\text { Consolidated } \\
\text { budget of } \\
\text { Ukraine, } \\
\text { mln hrn }\end{array}$ & $\begin{array}{l}\text { Revenue of } \\
\text { payments to } \\
\text { funds of state } \\
\text { social insur- } \\
\text { ance, mln hrn }\end{array}$ & $\begin{array}{c}\text { Budgetary } \\
\text { tax load, \% } \\
\text { of GDP }\end{array}$ & $\begin{array}{c}\text { Load of } \\
\text { payments } \\
\text { of social } \\
\text { insurance, \% } \\
\text { of GDP }\end{array}$ & Tax ratio \\
\hline 2006 & 544153 & 450015 & 125743 & 75843 & 27.9 & 16.9 & 0.448 \\
\hline 2007 & 720731 & 609018 & 161264 & 95473 & 26.5 & 15.7 & 0.422 \\
\hline 2008 & 948056 & 804900 & 227165 & 117091 & 28.2 & 14.5 & 0.428 \\
\hline 2009 & 913345 & 760816 & 208073 & 111119 & 27.3 & 14.6 & 0.420 \\
\hline 2010 & 1079346 & 874270 & 234448 & 134259 & 26.8 & 15.4 & 0.422 \\
\hline 2011 & 1299991 & 1037393 & 334692 & 152242 & 32.3 & 14.7 & 0.469 \\
\hline 2012 & 1404669 & 1129354 & 360567 & 178700 & 31.9 & 15.8 & 0.478 \\
\hline 2013 & 1465198 & 1188276 & 353968 & 188600 & 29.8 & 15.9 & 0.457 \\
\hline 2014 & 1586915 & 1290162 & 367512 & 181128 & 28.5 & 14.0 & 0.425 \\
\hline 2015 & 1988544 & 1610721 & 507636 & 185790 & 31.5 & 11.5 & 0.431 \\
\hline 2016 & 2383182 & 1939910 & 650782 & 131827 & 33.5 & 6.8 & 0.403 \\
\hline
\end{tabular}

Source: formed by the author, according to the data of the State statistic service, reports about completion of budget of the State treasury service of Ukraine, funds of obligatory state social insurance

Table 2

Calculation of tax losses as a result of shadow economy in Ukraine

\begin{tabular}{|c|c|c|c|c|c|c|c|c|c|c|c|}
\hline Year & $\begin{array}{c}\text { GDP, } \\
\text { mln hrn }\end{array}$ & $\begin{array}{c}\text { SE level, } \\
\% \text { of } \\
\text { GDP }\end{array}$ & $\begin{array}{c}\text { Budget- } \\
\text { ary TL, } \\
\quad \%\end{array}$ & $\begin{array}{c}\text { Load of } \\
\text { social } \\
\text { insurance } \\
\text { payments, } \\
\% \\
\end{array}$ & TR & $\begin{array}{c}\text { Tax } \\
\text { losses } \\
\text { of CBU, } \\
\text { mln hrn }\end{array}$ & $\begin{array}{c}\text { Tax } \\
\text { losses of } \\
\text { CBU, \% } \\
\text { of GDP }\end{array}$ & $\begin{array}{c}\text { Losses of } \\
\text { state social } \\
\text { insurance } \\
\text { payments, } \\
\text { mln hrn }\end{array}$ & $\begin{array}{l}\text { Losses of } \\
\text { state social } \\
\text { insurance } \\
\text { payments, } \\
\% \text { of GDP }\end{array}$ & $\begin{array}{l}\text { Total tax } \\
\text { losses, } \\
\text { mln hrn }\end{array}$ & $\begin{array}{c}\text { Total tax } \\
\text { losses, \% } \\
\text { of GDP }\end{array}$ \\
\hline 2006 & 544153 & 30 & 27.9 & 16.9 & 0.448 & 45614 & 8.4 & 27513 & 5.1 & 73127 & 13.4 \\
\hline 2007 & 720731 & 28 & 26.5 & 15.7 & 0.422 & 53437 & 7.4 & 31636 & 4.4 & 85073 & 11.8 \\
\hline 2008 & 948056 & 34 & 28.2 & 14.5 & 0.428 & 90973 & 9.6 & 46892 & 4.9 & 137865 & 14.5 \\
\hline 2009 & 913345 & 39 & 27.3 & 14.6 & 0.420 & 97417 & 10.7 & 52025 & 5.7 & 149442 & 16.4 \\
\hline 2010 & 1079346 & 38 & 26.8 & 15.4 & 0.422 & 109988 & 10.2 & 62986 & 5.8 & 172974 & 16.0 \\
\hline 2011 & 1299991 & 34 & 32.3 & 14.7 & 0.469 & 142601 & 11.0 & 64865 & 5.0 & 207466 & 16.0 \\
\hline 2012 & 1404669 & 34 & 31.9 & 15.8 & 0.478 & 152479 & 10.9 & 75570 & 5.4 & 228048 & 16.2 \\
\hline 2013 & 1465198 & 35 & 29.8 & 15.9 & 0.457 & 152761 & 10.4 & 81393 & 5.6 & 234154 & 16.0 \\
\hline 2014 & 1586915 & 43 & 28.5 & 14.0 & 0.425 & 194379 & 12.2 & 95800 & 6.0 & 290179 & 18.3 \\
\hline 2015 & 1988544 & 40 & 31.5 & 11.5 & 0.431 & 250684 & 12.6 & 91748 & 4.6 & 342433 & 17.2 \\
\hline 2016 & 2383182 & 34 & 33.5 & 6.8 & 0.403 & 271825 & 11.4 & 55063 & 2.3 & 326888 & 13.7 \\
\hline
\end{tabular}

Note: SE-shadow economy; TL - tax load; TR-tax ratio; CBU-Consolidated budget of Ukraine

Source: calculated by the author, according to the data of the State statistic service, reports about completion of budgets of the State treasury service of Ukraine, funds of obligatory state social insurance

\section{3. Other fiscal results of shadow economy}

The high shadow economy level and essential volumes of tax losses as a result of its functioning decrease financial possibilities of the state and provoke the budgetary deficit that prevents the policy of fiscal consolidation. It must be noted, that there is the permanent problem of imbalance of domestic budgets. Thus, in the period 2006-2016 the budget balance never had a surplus value, moreover in five of eleven studied years CBU deficit exceeded the maximal permissible volume as $3 \%$ of GDP (Table 3 ). 
It was impossible to set a direct correlation between the CBU deficit volume and shadow economy level empirically. It is connected with the policy of budget balancing, conducted by the public authorities. Under conditions of the lack of financial resources for decreasing the deficit level, budgetary expenditure volumes decrease maximally. So, shadow economy volumes influence the volume of the budget expenditure share. Our regression analysis proves such assumption. Yes, there is a rather close negative linear connection (Fig. 2) between growth rates of real CBU expenditures (Table 3) and shadow economy level, correlation coefficient is -0.7065 . This correlation is described by the model $y=-2.0312 x+1.7619$, approximation coefficient $\left(\mathrm{R}^{2}\right)$ of this model is 0.4991 . Thus, we make the conclusion that the shadow sector growth decelerates the growth of real CBU expenditures.

\section{Table 3}

Calculation of the deficit, real volumes of expenditures and capital expenditures of the Consolidated budget of Ukraine

\begin{tabular}{|c|c|c|c|c|c|c|c|c|c|c|}
\hline Year & $\begin{array}{c}\text { Official } \\
\text { GDP, mln } \\
\text { hrn }\end{array}$ & $\begin{array}{c}\text { CBU } \\
\text { incomes, } \\
\text { mln hrn }\end{array}$ & $\begin{array}{l}\text { CBU } \\
\text { expendi- } \\
\text { tures, mln } \\
\text { hrn }\end{array}$ & $\begin{array}{l}\text { CBU defi- } \\
\text { cit, mln } \\
\text { hrn }\end{array}$ & $\begin{array}{c}\text { CBU } \\
\text { deficit, \% } \\
\text { of GDP }\end{array}$ & $\begin{array}{l}\text { Index of } \\
\text { consump- } \\
\text { tion prices } \\
\text { (till Decemm } \\
\text { ber 2010) }\end{array}$ & $\begin{array}{l}\text { CBU, real } \\
\text { expendi- } \\
\text { tures, mln } \\
\text { hrn }\end{array}$ & $\begin{array}{l}\text { Growth } \\
\text { rate, } \%\end{array}$ & $\begin{array}{c}\text { CBU Capi- } \\
\text { tal expendi- } \\
\text { tures, mln } \\
\text { hrn }\end{array}$ & $\begin{array}{l}\text { CBU Cap- } \\
\text { ital expen- } \\
\text { ditures, \% } \\
\text { of GDP }\end{array}$ \\
\hline 2006 & 544153 & 168626 & 175284 & 6658 & 1.2 & 0.572 & 306441 & - & 24536 & $4.5 \%$ \\
\hline 2007 & 720731 & 219937 & 226054 & 6118 & 0.8 & 0.667 & 329740 & $107.6 \%$ & 38690 & $5.4 \%$ \\
\hline 2008 & 948056 & 297893 & 309204 & 11311 & 1.2 & 0.816 & 378926 & $114.9 \%$ & 41153 & $4.3 \%$ \\
\hline 2009 & 913345 & 272967 & 307399 & 34432 & 3.8 & 0.917 & 335223 & $88.5 \%$ & 20052 & $2.2 \%$ \\
\hline 2010 & 1079346 & 314506 & 377843 & 63337 & 5.9 & 1.000 & 377843 & $112.7 \%$ & 30648 & $2.8 \%$ \\
\hline 2011 & 1299991 & 398310 & 416854 & 18543 & 1.4 & 1.046 & 398522 & $105.5 \%$ & 41947 & $3.2 \%$ \\
\hline 2012 & 1404669 & 445454 & 492455 & 47000 & 3.3 & 1.043 & 472152 & $118.5 \%$ & 40745 & $2.9 \%$ \\
\hline 2013 & 1465198 & 442743 & 505844 & 63101 & 4.3 & 1.049 & 482215 & $102.1 \%$ & 29380 & $2.0 \%$ \\
\hline 2014 & 1586915 & 456067 & 523126 & 67058 & 4.3 & 1.309 & 399638 & $82.9 \%$ & 20200 & $1.3 \%$ \\
\hline 2015 & 1988544 & 652031 & 679871 & 27840 & 1.4 & 1.877 & 362212 & $90.6 \%$ & 46753 & $2.4 \%$ \\
\hline 2016 & 2383182 & 782859 & 835832 & 52973 & 2.2 & 2.109 & 396317 & $109.4 \%$ & 73130 & $3.1 \%$ \\
\hline
\end{tabular}

Source: calculated by the author, according to the data of the State statistic service, reports about completion of budgets of the State treasury service of Ukraine

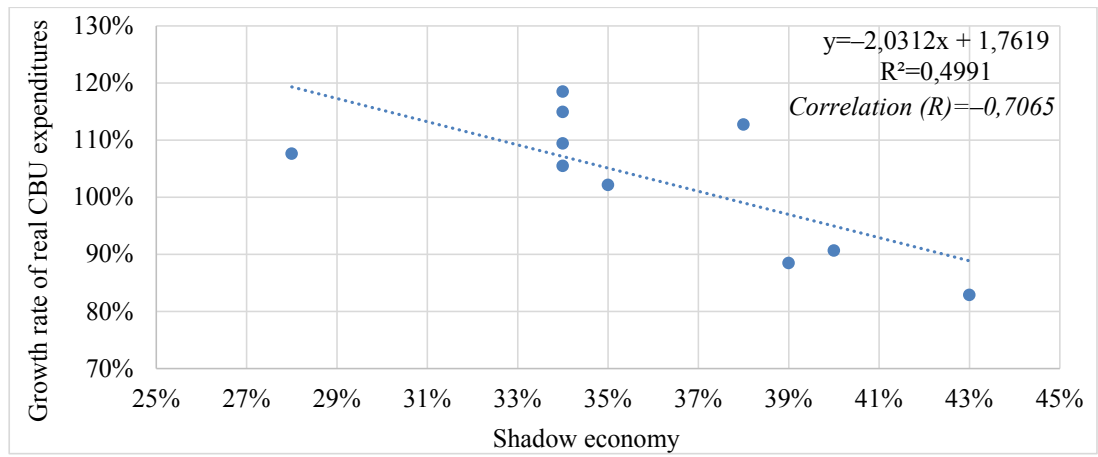

Fig. 2. Correlation between shadow economy and growth rate of real CBU expenditures in the period 2006-2016 Source: calculated by the author

Imbalance of state finances in Ukraine, manifested by the constantly existent negative budget balance, resulted in increasing the consolidated national debt. Its volumes moderately grew from $12.1 \%$ of GDP in 2006 to $32.8 \%$ of GDP in 2013, and as a result of the economic disturbance because of revolutionary events reached the minatory $69.3 \%$ of GDP in 2016 that exceeded the 
Maastricht criterion as $60 \%$ debt of GDP. The gradual change of the structure of CBU expenditures took place together with the debt growth. Thus, annual expenditures for debt servicing grew from $0.5 \%$ of GDP in 2007 to $4.0 \%$ of GDP in 2016. Such growth took place at the expanse of shortening expenditures for other extremely important directions such as health protection (from $3.7 \%$ of GDP in 2007 to $3.2 \%$ of GDP in 2016), education (from $6.2 \%$ to $5.4 \%$ ), economic activity (from $5.6 \%$ to $2.8 \%)$, general state functions $(2.9 \%-1.6 \%)$ [14].

The decrease of financing these directions has no positive influence on the quantity and quality of social services, provided by the state. Thus, the Government Effectiveness index in Ukraine in 2016, calculated by experts, was one of the lowest in Europe [15]. The low effectiveness of the work of the state sector is conditioned by the low wage level in it that also stimulates the corruption development that is a complementary component of the shadow economy in developing countries (that is testified by the empirical study [16]).

The growth of the debt load on the budget together with the necessity of the budgetary support of the impoverished population and lack of budget resources caused the decrease of an investment component of the domestic budget, namely capital expenditures of CBU from $5.4 \%$ of GDP in 2007 to $3.1 \%$ of GDP in 2016 (Table 3). The shortening of development expenditures will have essential negative socio-economic effects in future, because the untimely recreation of main funds of the state property will result in their final moral and physical destruction. The conducted regression analysis (Fig. 3) demonstrates the negative correlation $(\mathrm{R}=-0.8842)$ between the shadow economy level in Ukraine and CBU capital expenditures. This correlation is described by the linear model $y=-0.2457+0.1179$, and its reliability is proved by rather high approximation reliability coefficient $\left(\mathrm{R}^{2}\right)$, that is equal to 0.7818 . Such results are not unexpected, because at the lack of budgetary revenues, provoked by tax losses through the shadow economy, and because of peculiarities of the democratic politic regime in Ukraine (and not only), under which conditions the shortening of social budgetary expenditures is a complicated task because of a threat of decreasing politic ratings of the ruling elite, so most unnoticeable expenditures for society decrease, namely capital expenditures (ones of future).

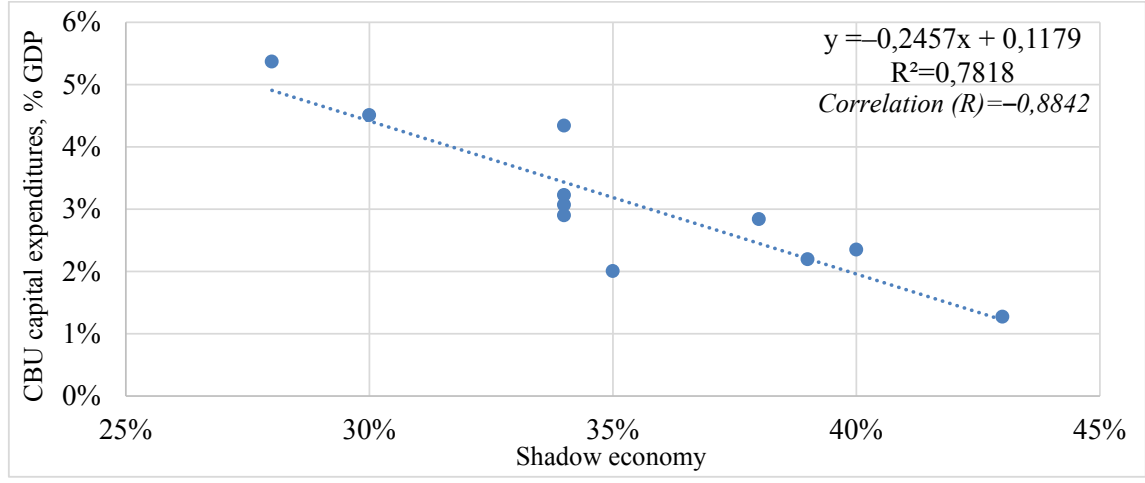

Fig. 3. Correlation between shadow economy and

CBU capital expenditures in the period 2006-2016

Source: calculated by the author

\section{Discussion of results}

Our results prove the theoretical assumptions of the scientific community about the baneful influence of essential shadow economy volumes on the fiscal sphere in Ukraine [17, 18]. This paper, as opposite to other ones, proves this influence by the empirical way that conditions the originality and importance of the research. Comparing the obtained indices of tax losses through the shadow economy in Ukraine with correspondent indices of European countries, calculated in the works by K. Raczkowski and F. Shneider [7, 8], we can make the conclusion that Ukraine is one of European leaders as to losses of tax revenues. Under such conditions it is rather difficult to talk about the possibility of implementing the policy of budgetary consolidation by the government. It is extremely difficult to provide the stability of state finances, if more than $1 / 3$ of GDP of the country is hidden and not taxed. 
The results of the study are unique in the context of empirical proof of the shadow economy influence of the volumes and structure of the expenditure budget share. The close negative correlation between the shadow economy level and volumes of CBU capital expenditures has been found for the first time.

From our point of view, in further studies it is important to search for ways of de-shadowing of the Ukrainian economy for augmenting the financial base of the budget. Before that the government must calculate and set the first strategic target (aim) that would cover the existent budget deficit.

\section{Conclusions}

The following conclusions may be formulated by the research results:

- The analysis of native and foreign studies of the shadow economy testifies to different approaches at calculating its volumes. They are the highest in studies of experts of the World Bank and vary within 40-47 \% of GDP. On the contrary, the lowest shadow economy level is determined by the Ukrainian statistic service - 15-20\%. From our point of view, the most distinct are the results of MEDTU that testify - 34-43\% of GDP.

- Ukrainian centralized funds of assets get less tax revenues in average by $15.4 \%$ of GDP, among them losses of budgets of different levels are $10.4 \%$ of GDP and ones of the Pension Fund of Ukraine $-5.0 \%$ of GDP. It must be noted separately, that after the abrupt change of the political vector in 2014, the budgetary tax load has a tendency to increase that is a result of the need of the consolidated budget in additional financial resources.

- Official data testify that the high shadow economy level in Ukraine conditions the permanent deficit of the domestic budget that results in the decrease of budgetary expenditures. The first directions of budgetary financing that suffer from the shadow economy are education, medicine, economic activity. At the same time the informal sector in the first turn conditions the decrease of an investment component of the domestic budget, namely capital expenditures of the consolidated budget.

Our conclusions prove the destructive effect of the shadow economy on state finances in Ukraine and condition the need in conducting further studies in this sphere for searching ways for its leveling.

\section{References}

[1] Schneider, F. (2016). The Size and Development of the Shadow Economies of Ukraine and Six Other Eastern Countries over the Period of 1999-2015. Ekonomika rozvytku, 2, 12-20.

[2] Medina, L., Schneider, F. (2017). Shadow Economies around the World: New Results for 158 Countries over 1991-2015. CESifo Working Paper Series No. 6430. Available at: https://papers.ssrn.com/sol3/ papers.cfm?abstract_id=2965972

[3] Hassan, M., Schneider, F. (2016). Size and Development of the Shadow Economies of 157 Countries Worldwide: Updated and New Measures from 1999 to 2013. IZA Discussion Paper No. 10281. Available at: http://ftp.iza.org/dp10281.pdf

[4] Ladiuk, O. (2017). Kharakterystyka tinovoi ekonomiky v Ukraini. Ekonomika ta derzhava, $8,32-34$.

[5] Pushak, Ya., Vinichuk, M. (2017). Riven tinovoi ekonomiky Ukrainy ta yii vplyv na sotsialnu komponentu ekonomichnoi bezpeky derzhavy. Naukovyi visnyk Khersonskoho derzhavnoho universytetu. Seriya: Ekonomichni nauky, 2, 139-143.

[6] Pirnykoza, P. (2016). Fiskalni ta ekonomichni naslidky tinovoi ekonomiky. Ekonomika ta derzhava, 9, 84-88.

[7] Raczkowski, K. (2015). Measuring the tax gap in the European economy. Journal of Economics and Management, 21 (3), 58-72.

[8] Schneider, F. (2015). Tax Losses due to Shadow Economy Activities in OECD Countries from 2011 to 2013: A preliminary calculation. Available at: http://www.econ.jku.at/members/Schneider/files/publications/2015/TaxLosses.Pdf 
[9] Nakaz Derzhkomstatu Ukrainy «Metodolohichni polozhennia obchyslennia obsiahiv ekonomiky, yaka bezposeredno ne sposterihaietsia» vid 31.12.2004 r. No. 680. State Statistics Service of Ukraine. Available at: http://www.ukrstat.gov.ua/metaopus/2017/2_02_02_01_2017.htm

[10] Nakaz Derzhkomstatu Ukrainy «Metodyka rozrakhunku valovoho vnutrishnoho produktu vyrobnychym metodom i za dokhodamy» vid 08.11.2004 r. No. 610. State Statistics Service of Ukraine. Available at: http://www.ukrstat.gov.ua/metaopus/2017/2_02_02_01_2017.htm

[11] Nakaz Ministerstva ekonomiky "Pro zatverdzhennia Metodychnykh rekomendatsiyi rozrakhunku rivnia tinovoi ekonomiky" vid 18.02.2009 r. No. 123. Ministry of Economic Development and Trade of Ukraine. Available at: http://www.me.gov.ua/LegislativeActs/Detail?lang=uk-UA\&id=4bb297a0-c900404f-8c6f-5f $76 \mathrm{f} 18 \mathrm{~b} 1503$

[12] Official website of the Ministry of Economic Development and Trade of Ukraine. Available at: http://www.me.gov.ua/?lang=uk-UA

[13] Official website of the State Statistics Service of Ukraine. Available at: http://www.ukrstat.gov.ua

[14] Official website of the State Treasury Service of Ukraine. Available at: http://www.treasury.gov. ua/main/uk/index

[15] Official web-site of the World Bank. Available at: https://data.worldbank.org/data-catalog/ worldwide-governance-indicators

[16] Dreher, A., Schneider, F. (2009). Corruption and the shadow economy: an empirical analysis. Public Choice, 144 (1-2), 215-238. doi: 10.1007/s11127-009-9513-0

[17] Filo, M. M. (2011). Podatkovi vtraty: teoretychnyi aspect. Naukovi zapysky [Natsionalnoho universytetu „Ostrozka akademiya”]. Ser.: Ekonomika, 17, 162-168.

[18] Pylypchenko, O. O. (2015). Vplyv tinovoi ekonomiky na ekonomichnu bezpeku Ukrainy. Stratehichni priorytety. Seriya: Ekonomika, 4, 32-36. 